\title{
EXPERIMENTS WITH ALL-KAPTON INSULATION AND AXIAL PRESTRESS IN 1.8 M-LONG SSC R\&D MAGNETS*
}

\begin{abstract}
P. Wanderer, M. Anerella, G. Cottingham, G. Ganetis, M. Garber, A. Ghosh, C. Goodzeit"*, A. Greene, R. Gupta, J. Herrera, S. Kahn, E. Kelly, A. Meade, G. Morgan, J. Muratore, A. Prodell, P. Radusewicz", M. Rehak, E. Rohrer, W. Sampson, R. Shutt, P.

Thompson, E. Willen, Brookhaven National Laboratory, Upton, New York 11973 -Superconducting Super Collider Laboratory, 2550 Beckdeymeade Ave., Dallas, TX 75237
\end{abstract}

Abstract

Several $1.8 \mathrm{~m}$-long magnets hrve been built to evaluate possible veriations in the dexign of the SSC collider dipoles. Except for length and the parnmeters being teated, thew models have the fectures of $40 \mathrm{~mm}$ aperture collider dipoles, which are based on a two-layer cosine theth coil. In these magnets, we hrve teated all-Kipton cablo insulation and the effects of chenges in the axill coil prestrem. Contruction details and test result for quenching, field harmonics, and coil loading are reported.

\section{INTRODUCTION.}

The magnets reported here hrve a two-layer coil, with $40 \mathrm{~mm}$ aperture and $80 \mathrm{~mm}$ outer diameter (Fig. 1). The coil cross-section (decignated C358D) is a four-wedge, non-radial block decign"ll. The etendard cable in oulation is a combination of the DuPant polyimide material "Kapton"th and epoxyimpregnated fiberglase. This peper reports teet reoults from magnets made with the atandard insolution and with an slternate, sll-Kepton insulation.

Other construction feetures included collers that are "anti-ovalized" ach that the vertical dimencion of the collen with prestreaned coils is reduced by sbout $0.010^{\circ}$ over thet which would be schioved with the nowinal geometry. A yolso currounds the collared coil; the iner ndine of the yolso Inminations was chowen to schieve linoto-line contuct with unctreased collare at room temperature. Stainless sted aboll were welded around the yoke and a ringle and plete made of $38.1 \mathrm{~mm}$ thickeses strinless teel was secured to the thell at each end of the megnet. Finnlly, end prelond was applied to the coils vin instrumented screws net into the end plete. This peper reports reaults due to the variation of the cad preload in one magnet. The megnet is dexigned to operate at $6.6 \mathrm{~T}$ central field in $4.35 \mathrm{~K}$ belinm with a curreat of $6.5 \mathrm{kA}$. Details of the magnet deciza not discused here aro deacribed elecwherets.

\section{EXPERIENCE WTTH ALL-KAPTON INSULATION}

The magnets with all-Kapton insulation teat a now

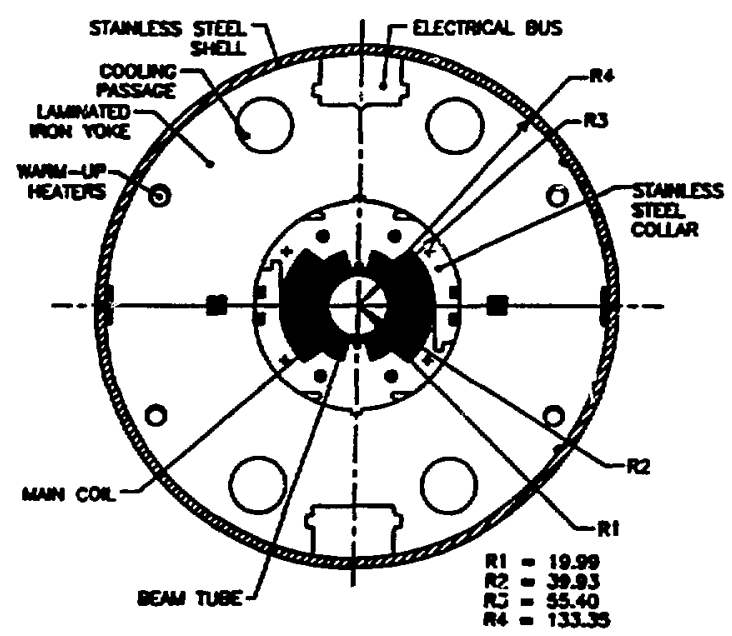

Fizure 1. Drawing of tho beseline, $40 \mathrm{~mm}$ aperture, collider dipole cold mess.

system of cable insulation which is presently being doveloped through a joint effort between BNL and DuPont. The sytem consints of two wreps of improved polyimide film coeted with a polyimide exthecive. It regleces tho present cable in aletion gyeen of ane wrep of polyimide film, overwryped with (B-

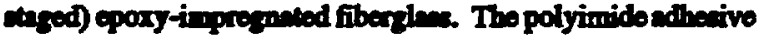
of the now innalation syctem is activeted immodiately upon reaching a benperature of 217 C. For comparion, the epoxy in the present eystem requires a cure cyclo of 90 minutes at $135 \mathrm{C}$. The tring for epplied coil presure during molding he been increanod from 7000 pai for the present oytem to 10,000 pei for the improved andem, to increave bond strength betweed cable turns.

The priscipal goul of the now syctem is to schieve greaber sedienace to cloctrical brenkdown between cable turms under compreavivs losd by increacing the strength, or "proschthrough reditence" of the cablo inmaletion. This he been demontrated through extenive tecting (coe Fig. 2). A ec00ed importent soul is to improve the redivition rexintence of the cable insolation system; this he been verified through independent materials teating. Secondary gouls, which are 


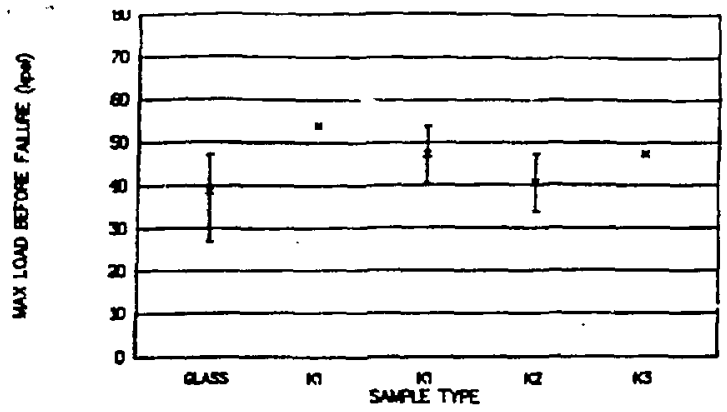

Figure 2. Punch through resistance of standand insulation (glass) and various types of allKapton insulation (k) in a test fixture. Each point represents the average of many tests; the errer bars show the range of test results.

expected improvements but hive not yet been verified, are improved conductor position uniformity and improved creep resistance. Finally, an unexpected benefit of the now insulation system which has been realized is an improved method for maintaining coil size repeatability, as indicated by initial testing.

Several variations of the improvod syotem have been used in different magnets. In most cases each wrap of polyimide is made with $50 \%$ overlyp coto itself, with the firat wrap being conted with a polyimide adbesive on its outside surface, and the second wrap being colted with the same sdhesive on both surfaces (K1). In some instances, a more porous wrap atyle was used for increased belium circulation around the cable. In this case, the first layer is made with $50 \%$ overlap onto itself but is unconted, and the recond layer is made as a non-overlap wrap with polyimide adhesive conted onto its outside surface only (K2). This variation of the cable insulation system most closely models the present Kepton/fiberglass cable insulation system. Recently, interest has subsided somewhat in the porous wrap variation, based on 1) the lack of evidence of Kapton divuption after teating (due to belium preseures after quench) found during inspection of a magnet made with the les porous ingulation, and 2) testing rubeequently completed on molded, compresed cable anples which demonstrated subetential, albeit reduced, belium flow through the polyimide cable insulation at modeat presaures.

Based on test results of an early magnet, where coil trees lowew due to thermal contriction effectu (after cooldown to 4 X) whers sinstured to be greation then those for similar Kepton/fibergines mignets, another variation of the improved cable insulation sydem has been tried. This vercion features a miserall filler added to the second wrap of polyimide film around the cable, to reduce the integrated thermal contraction of the film upon cooldown (K3). A comparieon of the atreses lose for various ingulation types can be seen in Figure 3. The filled polyimide abould also aid in greater creep resistance.

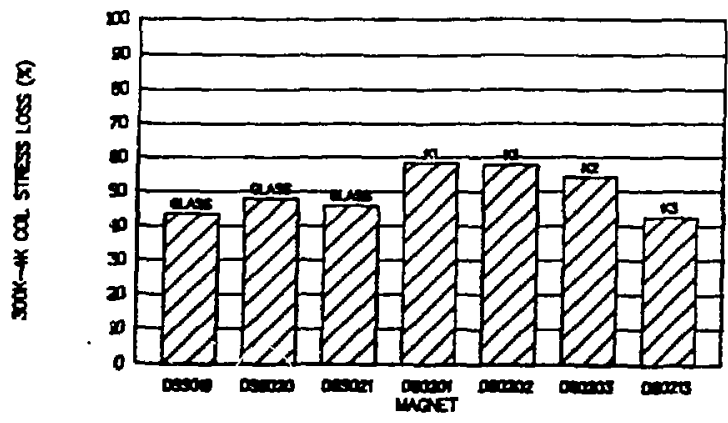

Figure 3. Croidown coil aximuthil stress loss for various ypes of cable insulation.

\section{MAGNET END LOADING STUDY}

It was found that the end preloud as measured by etrain gaugeds at one end of a magnet (DSO213) at room temperature (1200 lbs./ead) was lest during cooldown. As a test, the cad preload on one magnet was increseed to 2000 Ibs./end and the mignet relented. Although the atrin gauges till showed a los of prelond upon cooldown (Fig. 4), the quench performance was rubstantially improved (coe below). Lectly, the end prelond at room temperature was coirely removed, and the magnet quench-testad a third time. The quench performance (diecuseed in Section $\Gamma$ ) was not es good as with the $2000 \mathrm{lb}$. end preload.

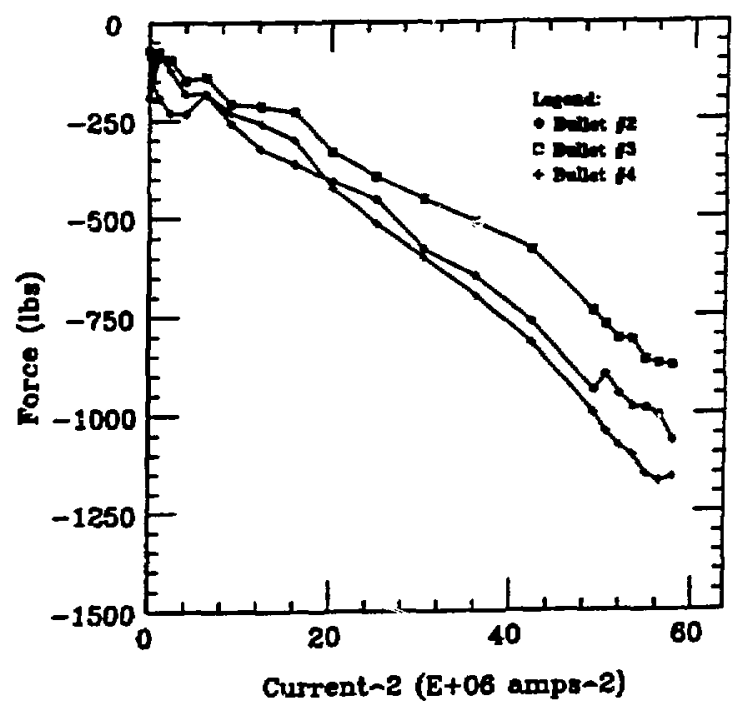

Figure 4. End force meavired at one end of a magnet by 3 of 4 trinin gauges (the 4 th whe non-functional). 


\section{MAGNET QUENCH PERFORMANCE DATA}

Magnets of both the standard Kapton glass cable insulation and the all-Kapton insulation reach the limit of the conductor at the three sto adard test temperatures $(4.35 \mathrm{~K}, 3.85$ K, $3.35 \mathrm{~K}$ ). Three recent magnets (DSSO19, LSSC20, DSS021) have standara Kapton/glass insulation but otherwise similar construction to tive all-Kapton magnets. The quench performance of DSSO20 is sypical (Fig. 5), with two outer coil queaches at $3.35 \mathrm{~K}$. The all-Yapton magnets appear to have somewhit more outer coil quenches, four in DSO203 (Fig. 6). DS0213 hed erratic quenching at $3.35 \mathrm{~K}$ but this was clearly improved by increasing the end loading of the magnet (Fig. $7)$. There is thus a suggestion that the all-Kopton magnets require a higher end preload to avoid outer coil queaches. Genenally spealing, it is plausible that the outer coil of a magnet with all-Kapton insulation would be more sensitive to heat deposition. In a magnet, the inner coil presses against the inner edge of the outer coil, raducing its porosity to belium relative to that of the inner coil.

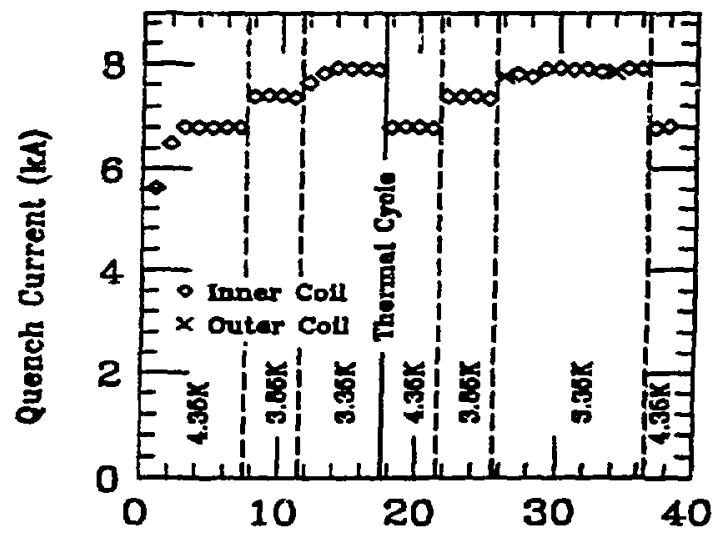

Figure 5. Queach performance of DSSO20.

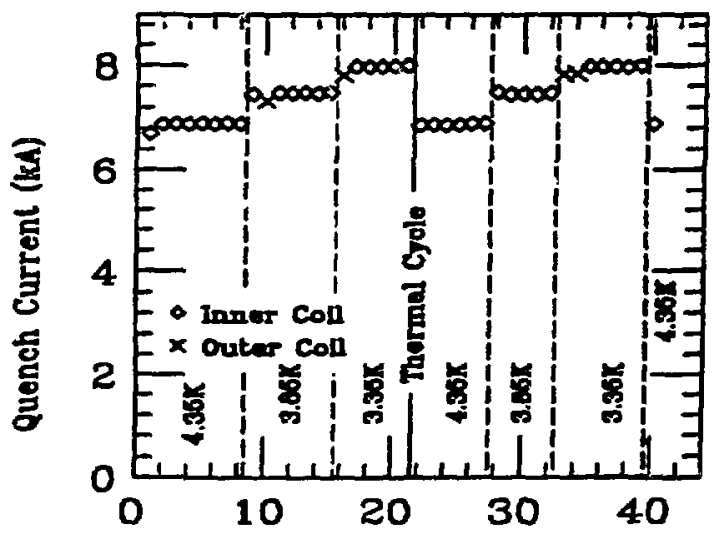

Figure 6. Quench performance of DSO203.

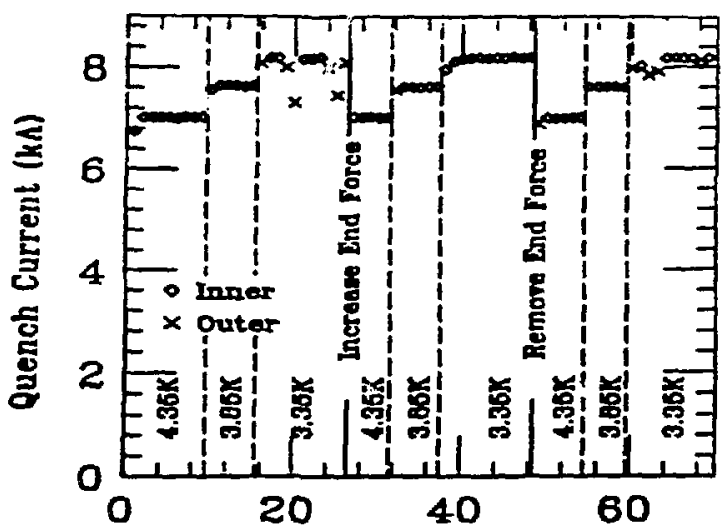

Figure 7. Queach performance of DSO213.

\section{HARMONICS}

The insulation used in these magnets varied in thickeses so it is not useful to compare harmonics between magnets. However it is interesting that the lowest-order harmonic which is sensitive to left-right size differences in the same coil, the normal quadrupole, is better in the tinree allKapton insulation magnets $(-0.04 \pm 0.10$ mits) then in the three standand-insulation mangnets $\left(0.58 \pm 0.30\right.$ units). ${ }^{\text {is }}$

\section{REFERENCES}

1. G. Morgan, "C358D: A Revision of the SSC Coil Design C358A," Megnet Division Note 225-1 (SSC-MD-183), Brookhaven National Laboratory, Upton, NY 11973 (1988).

2. "Kapton" is a registered trademark of the DuPont Corporation.

3. C. Taylor and P. Dahl, "Dipole Magaets: A Brief Description," in "SSC Conceptual Design Report Magnet Design Details," SSC-SR-2020B (1988).

4. C.L. Goodzeit, M. Anerella, and G. Genetis, "Forces in Superconducting Accelerator Magnets with Strain Guge Transdveers," IEEE Trans. Magnetics, 25, No. 2, pp. 1463.1468 (March, 1989).

5. A "unit" is $10^{4}$ of the dipole field at $10 \mathrm{~mm}$ mdius. 


\section{DISCLAIMER}

This report was prepared as an account of work sponsored by an agency of the United States Givernment. Neither the United States Government nor any agency thereof, nor any of their employees, makes any warranty, express or implied, or assumes any legal liability or responsibility for the accuracy, completeness, or usefulness of any information, apparatus, product, or process disclosed, or represents that its use would not infringe privately owned rights. Reference herein to any specific commercial product, process, or service by trade name, trademark, manufacturer, or otherwise does not necessarily constitute or imply its endorsement, recommendation, or favoring by the United States Governnient or any agency thereof. The views and opinions of authors expressed herein do not necessiarily state or reflect those of the United States Government or any agency thereof. 